\title{
Arch-last technique for total arch replacement using two-pump system in Stanford type A aortic dissection
}

\author{
C Park ${ }^{*}$, C Choi, Y Jeon, J Lee, K Park \\ From 23rd World Congress of the World Society of Cardio-Thoracic Surgeons \\ Split, Croatia. 12-15 September 2013
}

\section{Background}

Various cerebral protection methods are employed for aortic arch reconstruction. However, longer operation time and cerebral, cardiac and distal ischemic time impose a heavy burden on surgeons. This study demonstrates the clinical results and neurologic outcome with a modified cardiopulmonary bypass and antegrade cerebral perfusion in Stanford type A aortic dissection.

\section{Methods}

Between June 2005 and December 2012, 22 patients (16 men and 7 women), aged 28 to 76 years(mean $56.7 \pm$ 13.8), underwent total aortic arch replacement using antegrade selective cerebral perfusion through median sternotomy. Present pathologies were Stanford type A dissection (acute state in 19, chronic state in 3 patients), previous Bentall's procedure in 3 and previous descending thoracic aortic repair in two patients. Operations were performed with antegrade cerebral perfusion through two options: with right axillary artery, left common carotid artery and left subclavian artery, or without the latter. After anastomoses of descending aorta and proximal ascending aorta operation were performed, the three neck vessels were each anastomosed during heart-beating with two pumps which were used for both cerebral and distal perfusion.

\section{Results}

The mean duration of aortic clamping was $118 \pm 57$ min. The mean duration of circulatory arrest of the lower body and cerebral perfusion was $54 \pm 23 \mathrm{~min}$. The postoperative average time of orientation recovery was $9.5 \pm 7.5$ hours. There were 2 patients of in-hospital

* Correspondence: cdgpch@gilhospital.com

Department of Thoracic and Cardiovascular Surgery, Gachon University, Gil Hospital, Incheon, Korea mortality and 1 late death and no permanent neurologic deficit. Two patients underwent a staged reoperation for aneurysmal dilatation of residual descending aorta.

\section{Conclusion}

The arch-last reconstruction with antegrade cerebral perfusion had good neurological results, provided shortened ischemic time of heart and distal lower body. This would be an alternative strategy for less experienced surgeon.

Published: 11 September 2013

doi:10.1186/1749-8090-8-S1-P9

Cite this article as: Park et al:: Arch-last technique for total arch replacement using two-pump system in Stanford type $A$ aortic dissection. Journal of Cardiothoracic Surgery 2013 8(Suppl 1):P9.

Submit your next manuscript to BioMed Central and take full advantage of:

- Convenient online submission

- Thorough peer review

- No space constraints or color figure charges

- Immediate publication on acceptance

- Inclusion in PubMed, CAS, Scopus and Google Scholar

- Research which is freely available for redistribution

\section{Biomed Central}

( 2013 Park et al; licensee BioMed Central Ltd. This is an Open Access article distributed under the terms of the Creative Commons Attribution License (http://creativecommons.org/licenses/by/2.0), which permits unrestricted use, distribution, and reproduction in any medium, provided the original work is properly cited. 